\title{
Functional distribution of income and growth regime in Peru, 1942-2013
}

\author{
Germán Alarco Tosoni and César Castillo García ${ }^{1}$
}

\begin{abstract}
This paper begins by reviewing the literature on the relation between economic growth and the functional distribution of income since the time of the classical economists, highlighting the work of Kalecki and the post-Keynesians who develop the growthregimes approach. It reconstructs and analyses statistics on the shares of wages, income from self-employment (or from mixed sources) and profits in Peru's GDP between 1942 and 2013, and then compares these shares with the averages for Latin America and other economies. The study then makes a comparative analysis of trends in the wage share and rate of growth, and it estimates a simultaneous equations model using three-stage least squares (3SLS) and generalized method of moments (GMM) to determine the growth regime. The conclusion is that growth is wage-led, so distributional policies to increase this component would likely boost the level of economic activity.
\end{abstract}

\section{Keywords}

Income distribution, economic growth, measurement, income, wages, gross domestic product, Peru

\section{JEL classification}

E12, E25, F43, J30, O54

\section{Authors}

Germán Alarco Tosoni is a Research Professor at Pacífico Business School of the Universidad del Pacífico, Lima. Email: g.alarcotosoni@up.edu.pe.

César Castillo García is a Research Assistant at Pacífico Business School of the Universidad del Pacífico, Lima. Email: c.castillog@up.edu.pe. 


\section{Introduction}

The distribution of income is once again a topic on the international agenda and no longer just a matter of concern to classical economists, the regulationist school, post-Keynesians and Marxists. Its importance has even been emphasized in recent studies by the International Monetary Fund (IMF) and other international financial organizations. Excessive inequality erodes demand and the level of economic activity (Kumhof and Rancière, 2010; Ostry, Berg and Tsangarides, 2014; Cingano, 2014; Lakner and Milanovic, 2015); and it disrupts the social order (Figueroa, 2010; Stiglitz, 2015) and undermines the democratic system (Piketty, 2014; Oxfam, 2014).

Although, in recent decades, major efforts have been made to retarget studies towards the personal distribution of income, in the last few years other analyses have been made of how income is distributed between the different factors of production, although such studies for the Latin American economies are still few: Abeles, Amarante and Vega (2014); Alarco (2014); ILO (2012); ECLAC/ILO (2012); Neira (2010); Lindenboim (2008); Frankema (2009); Bértola and others (2008) and Fitzgerald (2009), among others. Most of this research still suffer from the problem that income from self-employment, or from mixed sources, is subsumed within gross operating surplus.

This study has two key objectives. First, it aims to reconstruct long series for the different components of the functional distribution of income in Peru: wages, income from self-employment and profits. While earlier studies covered 1950-2012, this one will span 1942-2013. Moreover, the profits and mixed-income component will be distinguished from the gross operating surplus series. Secondly, in line with post-Keynesian and regulationist studies, it will assess whether or not an increase in the GDP share of wages and mixed income contributes to the level of economic activity. If so, the economic growth regime would be wage-led; otherwise it would be profit-led. It is assumed that individuals reporting income from a mixture of sources (mainly peasant farmers and informal urban workers) can more reasonably be grouped among wage earners than with rentiers (recipients of profits).

The key hypothesis is that the share of wages in output has trended down since the 1980s. In the second case, the results in terms of the growth regime are useful for defining the distributional emphasis of the public policies which, according to historical evidence, are needed to help the economy continue growing. Since Kalecki (1954), the functional distribution of income has been a central element in explicitly explaining the level and trend of GDP. Starting with Boyer (1988a and 1988b) and Bhaduri and Marglin (1990) the growth regimes approach has been deepened to analyse the different transmission channels through which the wage share affects private consumption, private investment, exports and productivity.

The core of this paper has four sections, apart from the introduction and the conclusions. Section II discusses the literature that relates the income distribution to growth regimes. Section III displays the statistical series of the different components of income and presents the basic results on the trend of the GDP shares of wages, income from self-employment and profits. It also offers a number of explanatory factors for these shares and analyses Peru's track record relative to Latin America, the United States and the United Kingdom. Section IV describes the relationship between the wage share and economic growth in Peru, compared to that of Latin America as a whole; and section $V$ describes the simultaneous equations model chosen to identify Peru's economic growth regime for the period analysed, and it presents and analyses the results obtained.

The study has a macroeconomic focus, but does not consider structural or sociopolitical factors. It does not analyse relationships between the functional distribution and the personal distribution of income, nor does it consider the influences of technological phenomena and financialization. The paper does not make any policy recommendations for improving the income distribution and boosting economic growth, among other elements. 


\section{Distribution and economic growth regimes}

The relationship between distributional variables and economic growth is a longstanding issue; but it is made transparent in the economic flow of Quesnay (1980). Smith (1776) expresses an interest in improving the living conditions of the population and, in particular, the wages of workers who contribute to economic growth and ought to benefit from it. According to Ricardo (1821), economic growth is essentially the work of capitalists, who are the class responsible for the accumulation of capital. Marshall (1890), on the other hand, is unable to resolve the paradox that eliminated the entire distributional problem in the neoclassical school, insofar as an increase in the overall standard of living of the population increases both national welfare and efficiency, so it is not only a social but also an economic matter. After Marshall, any link between the wage share and the level of economic activity is broken.

The relation between the wage share and economic growth reappears with Keynes (1936), albeit implicitly, through the propensity to consume and the expenditure multiplier, and more clearly when general economic policy recommendations are established. ${ }^{2}$ Wages are the main component of income and determine the propensity to consume and, hence, the expenditure multiplier. Chapter 24 of General Theory of Employment, Interest and Money takes this further by considering the possibility of taxing income and inheritance, with the aim of increasing the community's propensity to consume. ${ }^{3}$

Kalecki (1954) explicitly determines the distribution of income, in particular of wages relative to income, from the price-setting process determined by supply, and later linked to the determination of demand and production. In the first phase, the share of wages in income depends on the degree of monopoly in the industrial sector in particular, the relationship between wages and raw materials in that activity (technical relationship) and the industrial structure. Thus, the wage share of income or output depends inversely on elements such as product differentiation (development of sales promotion through advertising), the existence of concentration processes and the presence of tacit agreements or cartels; and it depends directly on the strength of labour unions and another variable relating to the influence that the degree of monopoly has on variations in overheads relative to prime costs.

Kalecki also determines the level of demand and economic activity using profits as the explanatory variable, by applying the principle of effective demand per social group: capitalists earn what they spend, while wage-earners spend what they earn. Gross profits would thus be determined by the levels of consumption (dependent on the level of profits) and investment, net exports (exports minus imports) and the budget deficit. ${ }^{4}$ Subsequently, assuming that the wage bill depends on the level of output, the latter depends on profits subject to a multiplier that considers the share of wages in output. In short, when private investment, net exports and the budget deficit increase, output increases, depending on the multipliers associated with capitalists' propensity to consume and the share of wages in output. The more these increase, the more the latter will grow, and vice versa.

The discussion on growth regimes reappeared on the economics agenda starting with the French Regulation Theory School. In this connection, Bowles and Boyer (1988) developed the argument that the level of employment can respond positively or negatively to the level of real wages, which they call a wage-led or profit-led employment regime, respectively. Bhaduri (2007) and Bhaduri and Marglin (1990), writing from a post-Keynesian standpoint, provided a large part of the theoretical framework that served as a basis for evaluating growth regimes. Their aim was to develop a macroeconomic framework for analysing the relationship between wages and unemployment, evaluating the two basic perspectives in

2 This is pointed out by Kaldor (1955).

3 Taxes on income and inheritance would redistribute income from the rich to the poor, thereby raising society's average propensity to consume and increasing the expenditure multiplier.

4 This is true insofar as the private sector of the economy receives more through government expenditures than it pays in taxes. Strictly speaking, it would also be necessary to deduct the gross saving of capitalists and workers from gross profits. 
relation to real wages: either as a production cost (neoclassical approach), or as workers' purchasing power that stimulates demand. Stockhammer (2011) states that the identification of the dominant economic growth regime (wage- or profit-led) stems from an evaluation of how changes in the wage share affect demand and supply. In the case of demand, consumer spending is likely to be directly related to the wage share. In general, higher real wages will lead to a higher level of consumption expenditure because wage-earners have a higher propensity to consume than rentiers. Secondly, there is the possibility that investment will react negatively to an increase in the wage share (owing to a drop in the profit share or enterprise profit margins). Thirdly, net exports may react negatively to increases in the share of wages because, for a given exchange rate, profitability decreases, or exports become less competitive. Nonetheless, these effects will depend on the degree of trade openness and the type of products that are exported and imported.

In this regard, the net effect cannot be known ex ante, but will depend on the partial results. If the effect on the consumption side outweighs the effect on net exports and investment, the overall result is positive, and the economy is in a wage-led demand regime. Conversely, if investments and net exports react more strongly, the overall effect of an increase in the wage share on demand is negative and the demand regime will be profit-led. On the supply side, the key question is how changes in wage shares or real wages affect productivity growth (technological progress, from a broader perspective). The contribution could be either positive, in the framework of the Kaldor-Veerdoorn theory, or neutral or negative, according to orthodox economists.

There are many empirical studies on growth regimes, of which Stockhammer and Ederer (2007) highlight two types. The first group address the subject by estimating a structural vector autoregression (VAR) model. The advantage of this approach is that the interactions between the different variables are incorporated; but the disadvantage is that this makes it difficult to identify the effects of the individual variables. In the second group of studies, consumption, investment and net exports equations are estimated in terms of reduced forms, without considering the latest advances in econometrics and ignoring the unit roots problem. Accordingly, there is a tendency to apply error-correction models. The estimated models tend to be restricted to the theoretical models specified. Later, the econometric analysis was deepened, by expanding the range of control variables and incorporating other topics, such as the evaluation of the effects of globalization and financialization.

In the first group, Stockhammer and Onaran (2004) analyse the relationship between effective demand, income distribution and unemployment in the United States, France and the United Kingdom, using a structural VAR model, in the tradition of Kalecki and Kaldor. The second group of models focused on estimating the effects of changes in real wages or the GDP shares of wages and salaries on private consumption, private investment and net exports. These studies include Naastepad and Storm (2007), who evaluated the demand regime in the leading economies of the Organization for Economic Cooperation and Development (OECD) for the 1960-2000 period. Stockhammer and Ederer (2007) analysed the case of Austria; and later Stockhammer, Onaran and Ederer (2009) carried out research on 12 European economies with varied results.

For the specific case of Germany, Stockhammer, Hein and Grafl (2011) find that a reduction in the wage share typically has a contractionary effect on demand, while net exports are expansionary, depending on the degree of openness of the economy. Globalization can thus transform a wage-led regime into a profit-led one, which therefore calls for a detailed analysis. Onaran, Stockhammer and Grafl (2009 and 2011) incorporate the issue of financialization in an open economy into the debate and empirical analysis, considering the case of the United States. Onaran and Galanis (2012) evaluated the economies of the Group of Twenty (G-20) (including Argentina, Canada, China, India, Mexico, the Republic of Korea, South Africa and Turkey) and obtained some interesting findings (ILO (2011) provides a summary on the subject). Alarco (2016), using the Naastepad and Storm model (2007), determined the economic growth regime for 16 Latin American economies using ordinary least squares (OLS) for 
the period spanning 1950-2012. Argentina, the Bolivarian Republic of Venezuela, Brazil, Colombia, Costa Rica, Ecuador, El Salvador, Mexico, Paraguay, Peru and Uruguay appear to have a wage-led growth regime, while, Chile, Honduras, Nicaragua, Panama and the Plurinational State of Bolivia are found to be under a profit-led regime.

In critiques of the growth-regimes approach, Nikiforos (2014) argues that an economy cannot be permanently driven by profits or by wages. Palley (2014) notes that it is impossible to classify an economy into one economic growth regime or another, since this depends on the policies that are applied. Moreover, the econometrics used to typify the growth regime can change with economic policy: changes in the property structure, tax policies and financialization and others. The author refers to several cases in which the growth regime could be based on wages or profits when in fact the results show the opposite. Furthermore, the approach can be excessively deterministic by establishing ex ante the policies that are associated with each economic growth regime.

\section{Basic statistics, some explanatory factors and comparative analysis}

The series for the functional distribution of income were reconstructed from official data spanning 1942-2013 obtained from the Central Reserve Bank of Peru (BCRP), the National Institute of Statistics and Informatics (INEI) and the Ministry of Finance and Trade. Nominal GDP and its components on the income side (share of product taxes and subsidies and share of fixed capital consumption) were reconstructed using the formula specified in Pedagua (2009). In the case of income from self-employment, mixed agricultural and non-agricultural income had to be reconstructed from the previous sources and the production index proposed by Seminario (2015). In the case of the non-agricultural component, information from García (2013) was also used. Profits were obtained as a residual. Full details of the methodology used are provided in Castillo (2015).

Figures 1 and 2 show the observed data and the non-linear trend, applying the Hodrick-Prescott filter for the wage share, self-employment income and profits relative to GDP. In the case of the wage share, the peak occurs in the 1960s, followed by falls in the 1970s and 1980s and up to the first five years of the 1990s. The second half of that decade saw a recovery, although with a slight contraction in the last few years of the statistical series. The GDP share of income from self-employment also clearly trends downwards, albeit with slight growth in the 1980s and 1990s. In contrast, the trend of profits is upward, but cyclical, with larger shares in the 1950s and 1970s and again from the second half of the 1990s to the present.

To explain the trends shown in figures 1 and 2, domestic and international structural factors, sociopolitical and institutional elements, external events, technical elements, economic policy outcomes and other short-term issues all need to be considered. This is not a simple matter. To start with, the larger share of wages in GDP in the 1960s reflects the Fordist growth style, which was the international and local practice at the time. The aim was to maintain a balance between profits and wages. This was a period of migration to the cities, urbanization, improvement of social security systems and working conditions, and the growth of the middle class. In the Peruvian case, the initial loss of wage share occurs after the first macroeconomic adjustments and the deterioration of the terms of trade in the 1970s, between the first and second periods of military government. The next significant drop in the wage share occurs in the latter part of the 1980s, when the macroeconomic adjustments that staved off the effects of the Latin American debt crisis in Peru conspired with the severe fiscal and monetary macroeconomic imbalances that formed in 1987 and much of 1988, compounded by the effects of terrorism and the deterioration of the international economic situation. The steepest fall in the wage share occurs with the adjustment and stabilization policies of the Fujimori government in July 1990, 
which has sequels throughout that five-year period. Thereafter, the wage share improves until the boom in commodity prices (especially mining products), which increase the share of profits in GDP at the expense of the wage share.

Figure 1

Peru: GDP shares of wages and income from self-employment, 1942-2013 (Percentages)

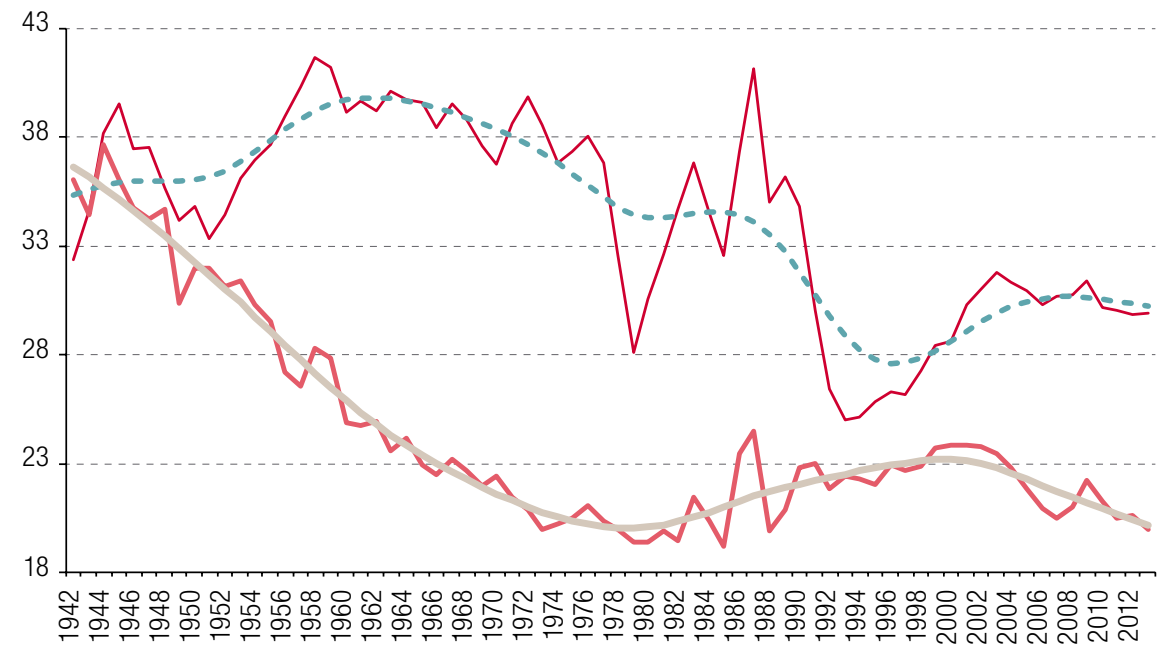

$$
\begin{array}{ll}
\text { - Share of wages } & \text { Share of income from self-employment } \\
\text { - - Trend share of wages } & \text { Trend share of income from self-employment } \\
\text { (Hodrick-Prescott Filter) } & \text { (Hodrick-Prescott Filter) }
\end{array}
$$

Source: Prepared by the authors, on the basis of Central Reserve Bank of Peru; National Institute of Statistics and Informatics (INEI); and N. García, "Fast economic growth and income distribution (Peru 1990-2010)", Economie Appliquée, No. 1, 2013 [online] http://www.itf.org.ar/pdf/documentos/89_2013.pdf.

Figure 2

Peru: share of profits in GDP, 1942-2013

(Percentages)

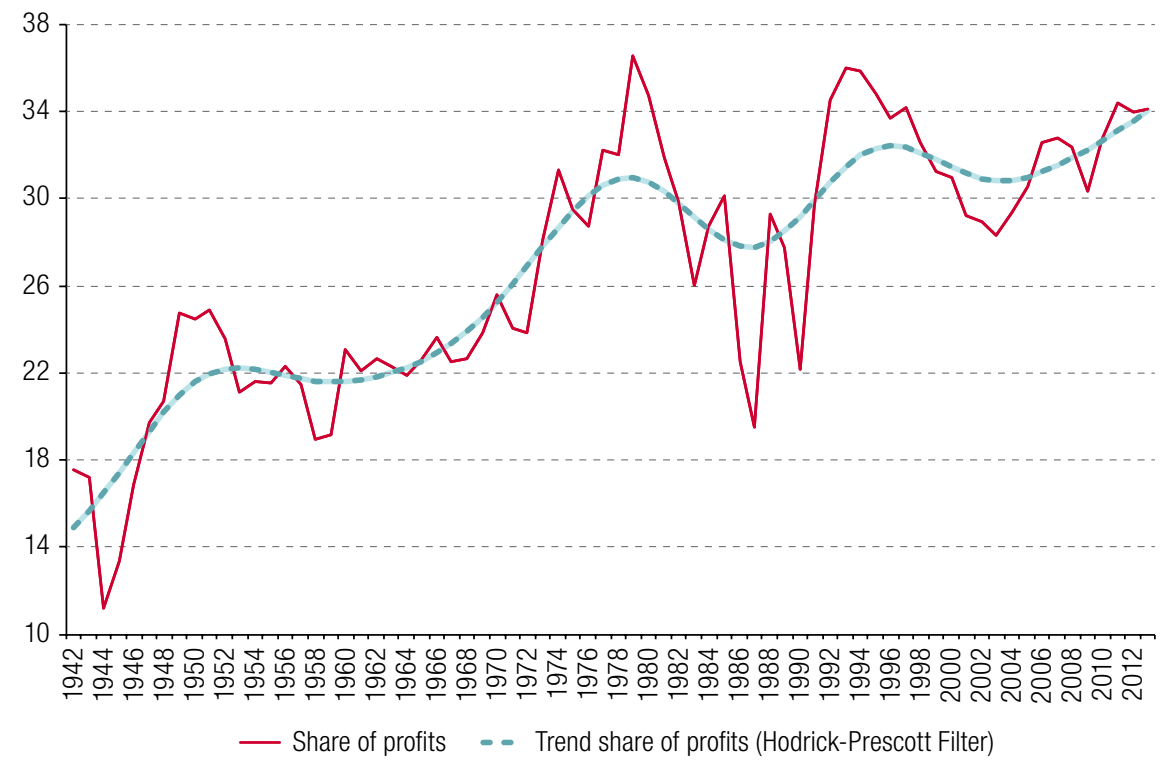

Source: Prepared by the authors, on the basis of Central Reserve Bank of Peru; National Institute of Statistics and Informatics (INEI); and N. García, "Fast economic growth and income distribution (Peru 1990-2010)", Economie Appliquée, No. 1, 2013 [online] http://www.itf.org.ar/pdf/documentos/89_2013.pdf. 
The migration and urbanization process, together with the growth of secondary sectors and the deterioration of the terms of trade to the detriment of agriculture, fuel the drastic fall in income from self-employment, mainly in rural areas. Nonetheless, while the share of wages in GDP falls during the 1990s, the urban self-employed (microenterprise owners and the informal economy) increased their GDP share before seeing it decline slightly in recent years. In contrast, the share of profits in output has been trending upwards, with cycles that seem to reflect the improvement and deterioration of the external terms of trade and the greater share of the extractive sector (mining and hydrocarbons) at the end of the 1940s, in the second half of the 1970s and since the last export boom which seems to end in 2012.

The foregoing, more structural, explanation, of trends and fluctuations in the GDP shares of wages, income from self-employment and profits can be supported by other more instrumental economic variables: inflation, external terms of trade, trend of interest rates, minimum real living age and oil prices. Nonetheless, it is impossible to obtain a single function that explains the shares of the various components of the functional distribution of income, since the statistical series that could serve as explanatory variables do not have the same periodicity; or else they are discontinuous, such as the agricultural producer price series, which is useful for explaining the agricultural component of self-employment income. Moreover, when the different exogenous variables are incorporated jointly, autocorrelation problems and other econometric difficulties arise. Table 1 shows some explanatory functions of the share of wages in GDP, which highlight the effects of inflation, external terms of trade, the nominal active interest rate, the real minimum living wage and oil prices.

Table 1

Some explanatory regressions of the share of wages in GDP

\begin{tabular}{|c|c|c|c|c|c|}
\hline Equation (dependent variable W/GDP) & Equation 1 & Equation 2 & Equation 3 & Equation 4 & Equation 5 \\
\hline c & $\begin{array}{c}0.356494 \\
(80.1382)^{*}\end{array}$ & $\begin{array}{c}0.259283 \\
(9.3968)^{*}\end{array}$ & $\begin{array}{r}0.349882 \\
(13.1080)^{*}\end{array}$ & $\begin{array}{r}0.276359 \\
(14.2438)^{*}\end{array}$ & $\begin{array}{r}0.318823 \\
(42.4157)^{\star}\end{array}$ \\
\hline Inflation & $\begin{array}{l}0.001294 \\
(2.8833)^{\star}\end{array}$ & $\begin{array}{l}0.000455 \\
(2.0963)^{*}\end{array}$ & & $\begin{array}{r}0.000533 \\
(0.4095)\end{array}$ & $\begin{array}{l}0.005212 \\
(2.4207)^{\star}\end{array}$ \\
\hline Nominal interest rate on loans & & & & $\begin{array}{r}0.001171 \\
(0.5410)\end{array}$ & $\begin{array}{r}-0.006496 \\
(-1.8402)\end{array}$ \\
\hline Minimum real living wage & & $\begin{array}{r}0.0000685 \\
(4.2049)^{*}\end{array}$ & & $\begin{array}{l}0.000157 \\
(6.1852)^{*}\end{array}$ & \\
\hline External terms of trade $(1954=100)$ & & $\begin{array}{r}-0.000504 \\
(-3.4566)^{*}\end{array}$ & & $\begin{array}{l}-0.000367 \\
(-2.9873)^{*}\end{array}$ & \\
\hline Nominal Brent oil price & & & $\begin{array}{r}-0.0004 \\
(-1.4995)\end{array}$ & & \\
\hline Dummy variable $(1979,1989-2000)$ & $\begin{array}{l}-0.084574 \\
(-7.5886)^{*}\end{array}$ & & & & $\begin{array}{r}-0.040128 \\
(-3.4666)^{*}\end{array}$ \\
\hline $\begin{array}{l}\text { Dummy variable } \\
(1990-2000)\end{array}$ & & & & $\begin{array}{l}-0.028254 \\
(-2.6915)^{\star}\end{array}$ & \\
\hline $\mathrm{AR}(1)$ & & $\begin{array}{l}0.805101 \\
(8.8849)^{*}\end{array}$ & $\begin{array}{r}0.903094 \\
(15.9866)^{*}\end{array}$ & & \\
\hline $\mathrm{R}^{2}$ & 0.45528 & 0.880755 & 0.849168 & 0.866923 & 0.479054 \\
\hline $\mathrm{F}$ & 28.83525 & 83.09322 & 168.8968 & 27.36059 & 7.356676 \\
\hline DW & 0.507641 & 1.712992 & 1.589216 & 1.880992 & 0.675966 \\
\hline Period & $1942-2013$ & 1962-2012 & 1950-2013 & 1986-2013 & 1986-2013 \\
\hline
\end{tabular}

Source: Prepared by the authors, on the basis of Central Reserve Bank of Peru; National Institute of Statistics and Informatics (INEI); International Monetary Fund (IMF); B. Seminario, El desarrollo de la economía peruana en la era moderna. Precios, población, demanda y producción desde 1700, Lima, University of the Pacific, 2015.

Note: t-statistics in parentheses below the parameters; an asterisk indicates that it is significantly different from zero at the $95 \%$ confidence level.

Throughout 1942-2013, inflation is a relevant variable for explaining the evolution of the share of wages in GDP. Nonetheless, both in periods of high inflation and hyperinflation; and when there is a clear policy to stifle wage increases (mainly when adjustment or stabilization policies are being implemented), there is a negative relationship that would explain $45 \%$ of the observations. If the real minimum living 
wage is added to the previous explanatory function, there is a positive contribution to the wage share. In that same equation, an improvement of the external terms of trade reduces the wage share, since profits are larger as a result of higher commodity export prices. Profits in the extractive sectors have a positive impact on profits in the economy at large, which reduces the share of wages in GDP. Similarly, both a rise in oil prices and an increase in interest rates on loans reduce the share of wages in output.

Figure 3 illustrates the comparison of the share of wages in Peru and in Latin America (Alarco, 2014) both with and without Peru. ${ }^{5}$ The Latin American series show a higher wage share than that of Peru alone, reflecting higher wage levels. After reaching a peak in the 1960s, the trend is downward, although falling more steeply in the Peruvian case since the mid-1970s (crisis between 1975 and 1978), while in the region as a whole there is a slight fall before the crisis of the 1980s, after which it climbs to another peak at the end of the first five years of the twenty-first century. The high inflation and hyperinflation registered in Peru between 1986 and 1990, followed by the adjustment programme in 1990-1994, generate a sharp drop in the share of wages in Peru, unlike what happened in the wider region. As from the second five years of the twenty-first century, while the wage share decreases in Peru, it increases regionwide, mainly owing to the boost to wages and the domestic market in Argentina and Brazil.

Figure 3

Peru and Latin America: trend of the share of wages in GDP (Percentages of GDP)

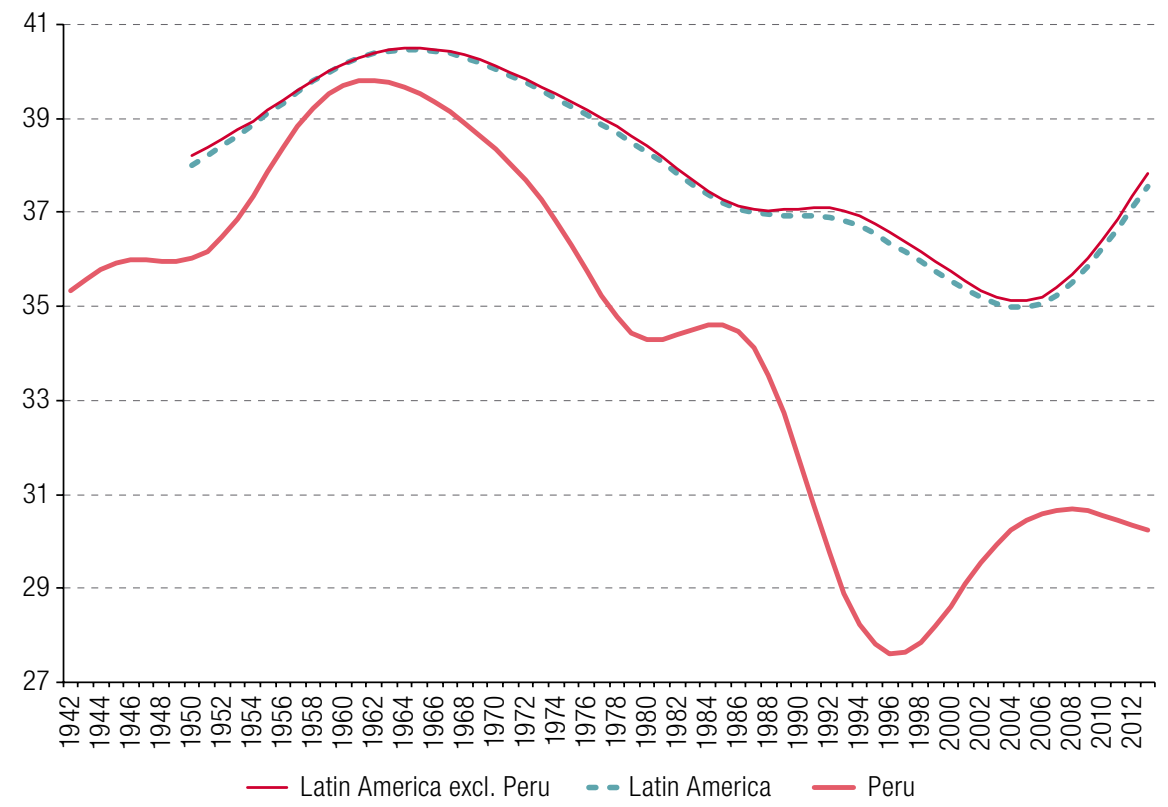

Source: Prepared by the authors, on the basis of Central Reserve Bank of Peru; National Institute of Statistics and Informatics (INEI); Economic Commission for Latin America and the Caribbean (ECLAC), "Statistics and Indicators" [online] http:// estadisticas.cepal.org/cepalstat/WEB_CEPALSTAT/estadisticasIndicadores.asp?idioma=i; World Bank, "World Development Indicators", 2014 [online] http://databank.worldbank.org/ddp/home.do?Step=1\&id=4); and G. Alarco, "Wage share and economic growth in Latin America, 1950-2011", CEPAL Review, No. 113 (LC/G.2614-P), Santiago, Economic Commission for Latin America and the Caribbean (ECLAC), 2014.

Figure 4 compares the GDP share of wages in Peru (left-hand scale) with those of the United States and the United Kingdom (right-hand scale), as examples of two major developed economies with comparable statistical series. These series are also corrected by the Hodrick-Prescott filter. The first difference to be noted is that the scale for the United States and the United Kingdom (which also include other forms of compensation such as contributions to pension, health and insurance funds) is

5 The three series are presented as non-linear trends having applied the Hodrick-Prescott filter to the observed data. 
clearly higher than Peru's scale. On the other hand, while the wage share fell continuously in Peru, but irregularly for the reasons mentioned above, in the United States the decline began in the 1980s, but has been more clearly visible since the mid-1990s. In the case of the United Kingdom, the share of wages in output began to fall in the 1970s. In Peru it peaked in the 1960s, while in the United States and the United Kingdom this happened in the following decade.

Figure 4

Peru, the United States and the United Kingdom: trend of the share of wages in GDP (Percentages of GDP)

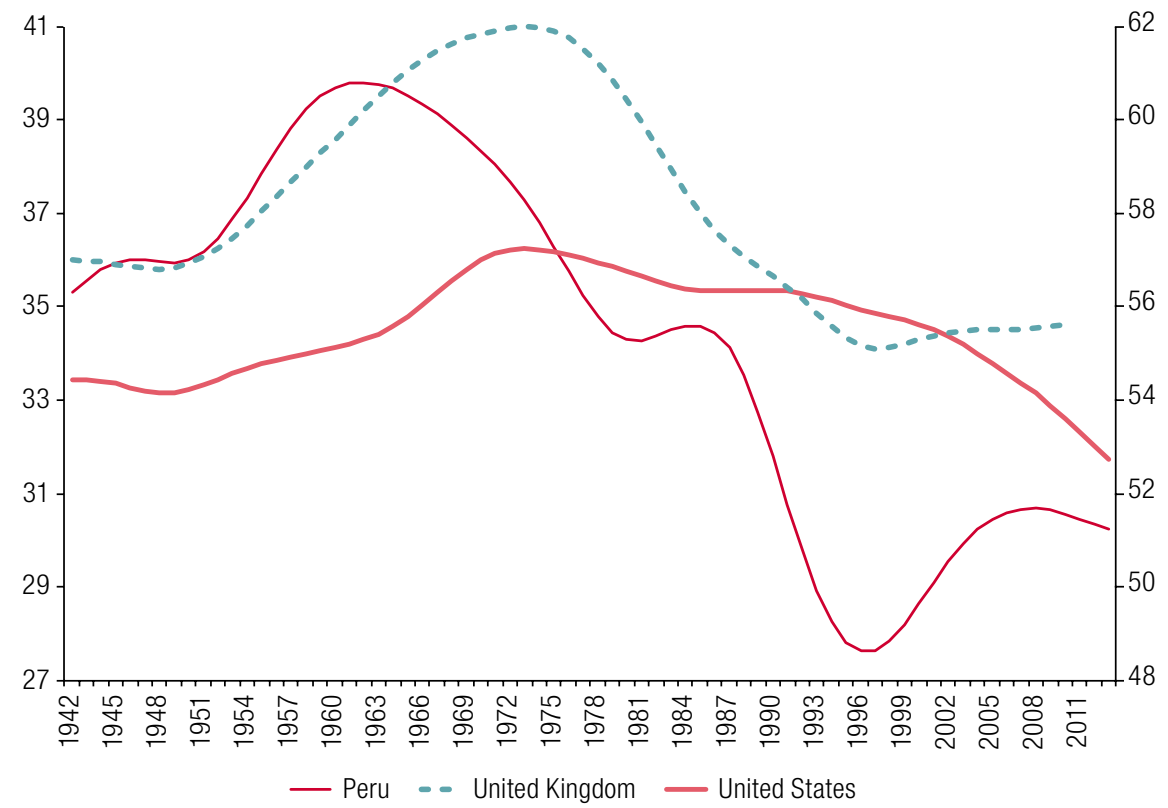

Source: Prepared by the authors, on the basis of Central Reserve Bank of Peru; National Institute of Statistics and Informatics (INEI); Bureau of Economic Affairs (BEA); and T. Piketty and G. Zucman, "Capital is back: wealth-income rations in rich countries, 1700-2010", Working Paper, Paris, Paris School of Economics, 2013.

\section{Relation between the share of wages and economic growth}

Figure 5 shows the decades-long path of economic growth and the GDP shares of wages in Peru and Latin America for the period under analysis. The results are obtained from the average of the wage share and the geometric mean of GDP growth in Peru and the region. It is useful to analyse whether there is a move from a less favourable situation to a better one, in which the wage share and economic growth both increase; or if there is a move from a better situation to a worse one when both variables decline; or if there is a trade-off with economic growth slowing while the wage share of GDP rises. This relationship also serves to graphically identify the periods in which the Latin American economy is wage-led (when the relationship is direct or positive) and when it is profit-led (when the relationship is negative).

The relation in the Peruvian economy clearly fluctuates more widely than that of Latin America as a whole, reflecting Peru's extreme variability. On the other hand, a general conclusion for Latin America is that between 1950 and 2013 the combination of the distributional structure and the economic growth rate has not been clearly advantageous. Both the share of wages in output and the rate of output growth have decreased. In Peru wages have lost share in the functional distribution of income, but the rate of economic growth has improved only slightly. Another relevant point in the Peruvian case is that only in the 1990s 
does a profit-led economy appear to predominate (shown by the negative gradient), while in the rest of the period -including the twenty-first century - the economy is predominantly wage-led. Economic growth had a high cost in distributional terms. In Latin America this occurs in the 1970s and again in the 1990s.

Figure 5

Peru and Latin America: path of the GDP share of wages and economic growth, 1950-2013 (Percentages)

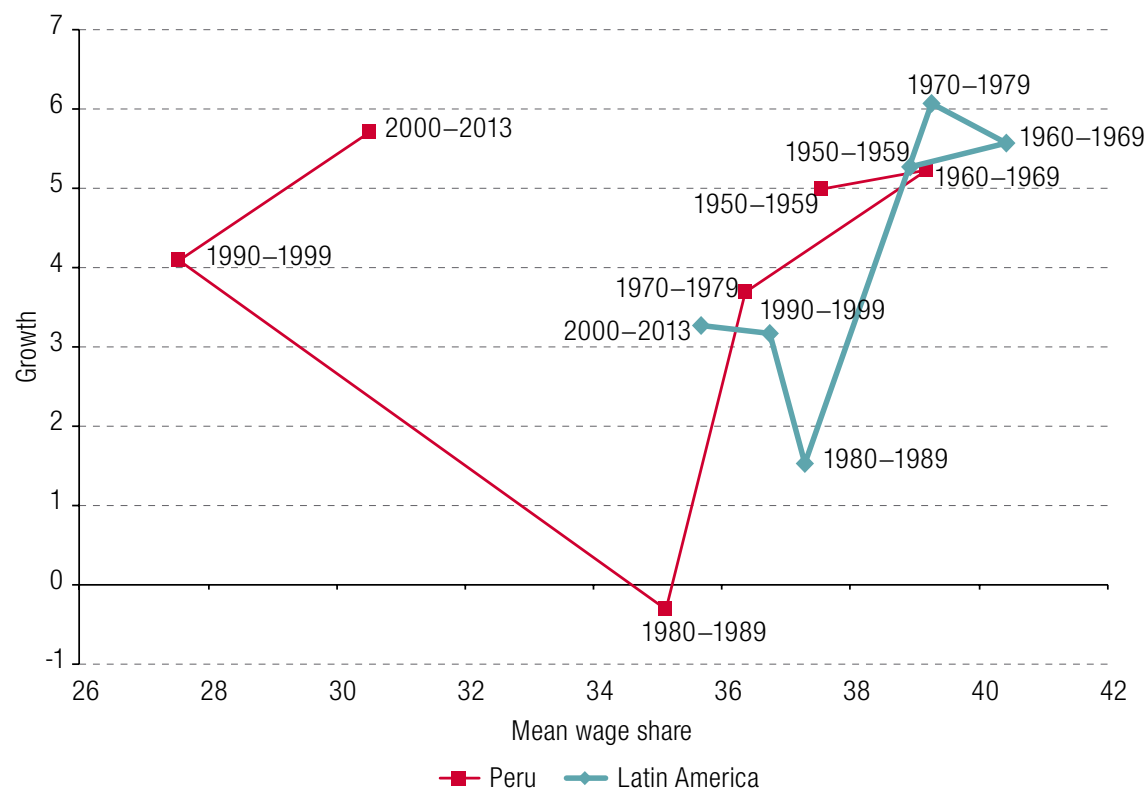

Source: Prepared by the authors, on the basis of Central Reserve Bank of Peru; National Institute of Statistics and Informatics (INEI); Economic Commission for Latin America and the Caribbean (ECLAC); and G. Alarco, "Wage share and economic growth in Latin America, 1950-2011", CEPAL Review, No. 113 (LC/G.2614-P), Santiago, Economic Commission for Latin America and the Caribbean (ECLAC), 2014.

\section{Model and economic growth regime in Peru}

The basic structural model used to evaluate the growth regime is a variant of that created by Naastepad and Storm (2007), which aims to evaluate the effect of a hypothetical change in output $(X)$ following a change in the GDP share of wages and income from self-employment. ${ }^{6}$ In equation (1) GDP at constant prices is described through the traditional expenditure-side identity, as the sum of private consumption (C), private investment (I), public consumption and public investment (G) and exports of goods and services $(E)$, less imports of goods and services $(M)$. Equation (2) defines private consumption as the propensity to consume of wage-earners and the self-employed $\left(\delta_{w}\right)$ multiplied by the adjusted wage share plus the sum of capital owners' (rentiers') propensity to consume $\left(\delta_{\pi}\right)$ out of profits (GDP minus the wage share). Private investment is shown in equation (3) as a linear function of profits and output (representing the accelerator effect of investment), with $\theta_{0}$ and $\theta_{1}$ the parameters of that variable, both of which are expected to be greater than zero. Exports of goods and services are shown in equation (4) as a linear function of global demand (Z), and depend on profits or GDP minus the wage bill, with $\varepsilon_{0}$ and $\varepsilon_{1}$ their respective parameters. Equation (5) expresses imports of goods and services as a linear function of the propensity to import $\left(\alpha_{1}\right)$ relative to output. All functions, except private consumption, have a constant term.

\footnotetext{
6 Hereinafter, this will be referred to as the "adjusted wage share" because the propensities to consume of employees and the self-employed are more similar to each other than to that of rentiers.
} 


$$
\begin{gathered}
X=C+I+G+E-M \\
C=\delta_{w} W+\delta_{\pi}(X-W) \\
I=f(\pi, X)=A_{I}+\theta_{0 \pi}+\theta_{1} X \\
E=g(Z, \pi)=A_{E}+\varepsilon_{0} Z+\varepsilon_{1} \pi \\
M=\alpha_{0}+\alpha_{1} X
\end{gathered}
$$

These equations are solved to measure the impact of a change in the adjusted wage share and income from self-employment in GDP. Equation (6) expresses the elasticity of output with respect to the adjusted wage bill $\left(E_{X W}\right)$, which is obtained by substituting equation (2) in equation (1), taking the derivative of output with respect to the adjusted wage bill relative to GDP. Public expenditure (both current spending and investment) is assumed to be insensitive to changes in the share of wages. The elasticity of private consumption with respect to the adjusted wage share in GDP is denoted by $E_{C W}$; the elasticity of private investment with respect to the adjusted wage share is represented by $E_{I W}$; and the elasticity of exports of goods and services with respect to the adjusted wage share in GDP is denoted by $E_{E W}$.

$$
E_{X W}=(C / X) E_{C W}+(I / X) E_{I W}+(E / X) E_{E W}-\alpha E_{X W}
$$

In equations (7), (8), (9) and (10) $E_{C W}, E_{I W}, E_{E W}$ and $E_{M W}$ are presented, respectively, as a result of differentiating equations (2), (3), (4) and (5) with respect to the change in the adjusted wage share. Equation (11) expresses the overall elasticity of output with respect to variations in the adjusted wage share, based on equations (6), (7), (8), (9) and (10). This reduced-form equation considers both the expenditure multiplier, which includes the propensity to consume of the owners of the means of production, and the parameters of private investment, exports relative to profits and the economy's propensity to import. The numerator contains the difference between the propensities to consume of employees and owners, the response of private investment to profits and the reaction of exports with respect to profits multiplied by the adjusted wage share of GDP. If the final result gives $E_{X W}>0$, a wage-led growth regime predominates, whereas if $E_{X W}<0$ the regime would be profit-led.

$$
\begin{gathered}
E_{C W}(C / X)=\left(\delta_{w}-\delta_{\pi}\right)(W / X)+\delta_{\pi} E_{X W} \\
E_{I W}(I / X)=\left(\theta_{0}+\theta_{1}\right) E_{X W}-\theta_{0}(W / X) \\
E_{E W}(E / X)=\varepsilon_{1} E_{X W}-\varepsilon_{1}(W / X) \\
E_{M W}(M / X)=\alpha_{1} E_{X W} \\
E_{X W}=\left[1 /\left(1-\delta_{\pi}-\left(\theta_{0}+\theta_{1}\right)-\varepsilon_{1}+\alpha_{1}\right)\right]\left[\left(\delta_{w}-\delta_{\pi}\right)-\theta_{0}-\varepsilon_{1}\right](W / X)
\end{gathered}
$$

The data used to apply the growth regime model was obtained from BCRP and INEI and from Ministry of Finance and Commerce (1959). International data was obtained from the United Nations and Maddison (2001) to complete the initial periods of world GDP. The shares of private consumption, private investment and exports with respect to GDP are represented by their average values for 1942-2013. 
The procedure used to determine the Peruvian economy's economic growth regime has three stages. First, all the parameters of the functions of private consumption, private investment, exports and imports of goods and services are estimated simultaneously, considering the variables contained in equations (2), (3), (4) and (5). ${ }^{7}$ The second stage consists of calculating the elasticity of private consumption with respect to the adjusted wage share of $\mathrm{GDP}\left(E_{C W}\right)$, the elasticity of private investment with respect to the adjusted wage share $\left(E_{I W}\right)$ and the elasticity of exports of goods and services with respect to the adjusted wage share $\left(E_{I W}\right)$, according to the formulas described in equations (9), (10) and (11). Lastly, these results are substituted in equation (10) relative to the elasticity of output with respect to the adjusted wage share of GDP $\left(E_{X W}\right)$ to evaluate whether $E_{X W}>0$, in which case economic growth is wage-led, or if $E_{X W}<0$, in which case the growth regime is profit-led.

The results for the different parameters have been estimated using two econometric techniques involving simultaneous equations: three-stage least squares (3SLS) and the generalized method of moments (GMM) using the Eviews software; the results are shown in table 2. In both cases, the number of observations is 72 years for each dependent and independent variable. Those considered at the start in equations (2), (3), (4) and (5) have not been augmented by other control or instrumental variables, lagged variables, or dummy variables to maintain the model's overall logic, comparability of results and ease of obtaining the corresponding elasticities.

Table 2

Peru: main functions explaining private consumption, private investment and exports, 1942-2013

\begin{tabular}{|c|c|c|c|c|c|c|c|}
\hline \multirow[b]{2}{*}{ Equation } & \multirow[b]{2}{*}{$\begin{array}{l}\text { Estimation } \\
\text { method }\end{array}$} & \multicolumn{5}{|c|}{ Independent variables } & \multirow[b]{2}{*}{ R2 } \\
\hline & & $\begin{array}{c}\text { Adjusted } \\
\text { wage share }\end{array}$ & Profits & GDP & Global demand & Constant & \\
\hline \multirow[t]{4}{*}{ Private consumption } & \multirow[t]{2}{*}{ 3SLS } & 0.9502 & 0.4366 & & & & \multirow[t]{2}{*}{0.9894} \\
\hline & & $(37.4587)^{\star \star \star}$ & $(9.8423)^{\star \star \star}$ & & & & \\
\hline & \multirow[t]{2}{*}{ GMM } & 0.8683 & 0.6764 & & & & \multirow[t]{2}{*}{0.9790} \\
\hline & & $(35.0889)^{\star \star \star}$ & $(14.3631)^{\star \star \star *}$ & & & & \\
\hline \multirow[t]{4}{*}{ Private investment } & \multirow[t]{2}{*}{ 3SLS } & & 0.0820 & 0.1636 & & $-7.14 \mathrm{E}+09$ & \multirow[t]{2}{*}{0.9005} \\
\hline & & & $\left(1.5290^{\prime}\right)$ & $(8.2325)^{\star \star \star}$ & & $(-4.9842)^{\star \star \star}$ & \\
\hline & \multirow[t]{2}{*}{ GMM } & & -0.1461 & 0.1409 & & $5.66 \mathrm{E}+08$ & \multirow[t]{2}{*}{0.5386} \\
\hline & & & $(7.1207)^{\star \star \star}$ & $(-2.2521)^{\star}$ & & $\left(0.6961^{\prime}\right)$ & \\
\hline \multirow{4}{*}{$\begin{array}{l}\text { Exports of goods and } \\
\text { services }\end{array}$} & \multirow[t]{2}{*}{ 3SLS } & & 0.2891 & & 0.0012 & $-6.22 E+09$ & \multirow[t]{2}{*}{0.9108} \\
\hline & & & $(6.5644)^{\star \star \star}$ & & $(14.1005)^{\star \star}$ & $(-4.9152)^{\star \star \star}$ & \\
\hline & \multirow[t]{2}{*}{ GMM } & & 0.0743 & & 0.0011 & $-1.44 \mathrm{E}+09$ & \multirow[t]{2}{*}{0.7486} \\
\hline & & & $(2.0605)^{\star \star}$ & & $(17.0941)^{\star \star}$ & $(-1.6829)$ & \\
\hline \multirow{4}{*}{$\begin{array}{l}\text { Imports of goods and } \\
\text { services }\end{array}$} & \multirow[t]{2}{*}{ 3SLS } & & & 0.2558 & & $-1.12 \mathrm{E}+10$ & \multirow[t]{2}{*}{0.9290} \\
\hline & & & & $(30.5657)^{\star \star \star}$ & & $(-7.3075)^{\star \star \star}$ & \\
\hline & \multirow[t]{2}{*}{ GMM } & & & 0.1511 & & $-1.66 \mathrm{E}+09$ & \multirow[t]{2}{*}{0.7076} \\
\hline & & & & $(16.8812)^{\star \star \star}$ & & $(-2.2626)^{\star \star \star}$ & \\
\hline
\end{tabular}

Source: Prepared by the authors, on the basis of World Bank; Central Reserve Bank of Peru; National Institute of Statistics and Informatics (INEI); United Nations; Ministry of Finance and Trade; and A. Maddison, The World Economy. A Millennial Perspective, Paris, Organization for Economic Cooperation and Development (OECD), 2001.

* Estimate significantly different from zero at $95 \%$.

** Estimate significantly different from zero at $99 \%$.

*** Estimate significantly different from zero at $99.5 \%$.

The results obtained for the different equations and parameters are reasonable, and the fits are better using 3SLS than they are with GMM. With the first method, the goodness of fit of the four equations fluctuates between 0.90 and 0.99 , while with GMM it is 0.54 in the case of private investment and between 0.7 and 0.98 for the other equations. In the 3SLS estimation, all parameters are significantly

7 All the variables are expressed in real terms. 
different from zero at the 99\% confidence level, except for the parameter that relates private investment to profits. In the case of GMM, there are problems in the parameters of the constant term for both private investment and exports. The parameters of private investment with respect to profits and of exports relative to profits are significantly different from zero at the $95 \%$ confidence level.

Under both estimation methods, wage-earners' propensities to consume are higher than those of rentiers -0.95 and 0.44 , respectively, under $3 S L S$, and 0.87 and 0.68 , respectively, with GMM. Other parameters worth mentioning are the GDP accelerator in private investment, which reports a value of 0.16 under $3 S L S$ and 0.14 with GMM. The difference in value and sign of the parameter relating private investment to profits is striking: in the case of 3SLS the parameter is 0.08 , while under GMM it is - 0.15 . The parameter of exports with respect to global demand is small because of the magnitude of the numbers in the statistical series of this variable: both estimation methods report a value of 0.001 . Lastly, the economy's propensity to import is estimated at 0.26 under 3SLS, but 0.16 under GMM. The values of the constant parameters are high.

Table 3 shows the results of the GDP components of private consumption, private investment, imports and exports, and the elasticity of GDP with respect to changes in the wage share of GDP in equation (10). The results for 1942-2013 are presented for both the 3SLS and the GMM methods. All cases consider the effect of a percentage change in the adjusted wage share for each component of demand in the same time period.

Table 3

Peru: components of demand and elasticity of the adjusted share of wages in GDP, 1942-2013

\begin{tabular}{lcc}
\hline Elasticities & Estimation with 3SLS & Estimation with GMM \\
\hline Elasticity of GDP with respect to wage share & 0.3601 & 0.3822 \\
\hline Private consumption component & 0.6776 & 0.5481 \\
\hline Private investment component & 0.4658 & 0.6631 \\
\hline Export component & -0.3387 & -0.0786 \\
\hline Import component & 0.6018 & 0.3774 \\
\hline Multiplier & 2.7286 & 2.4654 \\
\hline
\end{tabular}

Source: Prepared by the authors, on the basis of World Bank; Central Reserve Bank of Peru; National Institute of Statistics and Informatics (INEI); United Nations; Ministry of Finance and Trade; and A. Maddison, The World Economy. A Millennial Perspective, Paris, Organization for Economic Cooperation and Development (OECD), 2001.

In all cases, the private consumption component is positive owing to the difference between the propensity to consume of wage earners and the self-employed relative to that of owners of the means of production. Thus, an increase in the adjusted wage share increases private consumption. Similarly, the private investment component grows when the wage share increases, and displays procyclicality: the greater the growth of the wage share, the greater is private investment. In contrast, the export component is negative with respect to the wage share since it affects profits (and hence export returns). ${ }^{8}$ Conversely, an increase in the wage share increases imports and reduces GDP. The final result of the elasticity of output in response to a percentage increase in the wage share incorporates a multiplier of between 2.7 and 2.5 and gives a final value of between 0.36 and 0.38 under 3SLS and GMM, respectively. The elasticity of GDP with respect to changes in the adjusted wage share is positive, but inelastic. The economic growth regime for the period spanning 1942-2013 would therefore be wage-led, so distributional policies in favour of wages would likely boost economic activity.

8 The estimates reflect a positive relation between exports and profits, but it should be remembered that $75-80 \%$ of the former are traditional exports which are capital intensive and have grown more in line with the increase in the terms of trade, so this direct relationship could be non-causal. 


\section{Conclusions}

Although the relation between the functional distribution of income and economic growth was important for classical economists, it disappeared as an issue with the advent of the neoclassical school. The different social groups lost importance and were replaced by the distinction between consumers and producers; and Say's law dominated, whereby supply always creates its own demand. Only with Keynes, who recommended imposing income and inheritance taxes at times of crisis caused by a lack of demand, does the structure of the income distribution regain a role through its impact on the propensity to consume and then on the expenditure multiplier, which are tools for determining demand and the level of economic activity.

Kalecki transparently divides society into social groups, assigning each one specific functions and behaviour patterns, at both the firm and industry levels and for the macroeconomy in general. The distribution of income emerges out of the price-setting process, which involves wages, inputs, the market power held by owners of the means of production through the degree of monopoly, and other technical factors and coefficients. At the aggregate level, the economic activity rate depends on the share of wages in output, the different components of internal and external demand, and other elements. Improving the wage share of output will raise the level of demand and boost production.

The work of Boyer, Bhaduri and Marglin expands the range of possible outcomes in response to a variation in the share of wages in output. This is developed further by Stockhammer and other authors. A change in the wage share affects not only private consumption, as Kalecki predicted, but also private investment and net exports. The final effect on demand and on GDP will depend on the response values and the weight of each of the components. As in any approach, the appropriate methodology for evaluating these effects involves several factors.

A key element for analysing the functional distribution of income and determining Peru's economic growth regime involves constructing the statistical series of its different components. This is not as simple as it might seem, because the functional distribution of income has not been a relevant issue since the 1980s. There are problems of aggregation and in terms of continuity of the series in question. Long-term official statistics only report GDP on the demand side and by sectors of production, but not on the income side. Attention nowadays is focused on the personal distribution of income, forgetting, owing to the dominance of the neoclassical perspective, that income and distribution firstly depend on the position of individuals in the production process: wage earners, rentiers or owners of the means of production and the self-employed (mixed income). This article has presented and discussed the reconstructed series for these three components, distinguishing gross operating surplus from profits and from self-employment income. The statistical series are presented for the 1942-2013 period, in an exercise that could be applied to other economies in the region.

The non-linear trend of the GDP share of wages in Peru displays a decreasing sinusoidal form, with cycles that peak in the 1960s and start to decline from the mid-1970s onwards (domestic imbalances in the first and second periods of military government and the oil shock), followed by a steep decline lasting from the late 1980s until the mid-1990s (the new outward-looking model). From then on, the share of wages recovers, before flatlining towards the end of the period. In the case of the mixedincome share, the urbanization process and deterioration of agricultural prices generate a downward trend, with a minor upswing towards the end of the twentieth century and the start of the twenty-first. In contrast, the profit share is trending up, with individual upswings in the early 1950s, the second half of the 1970s, the 1990s and the start of the twenty-first century. These are largely explained by the rise in the prices of exported raw materials.

Both the level of the wage share in Peru's GDP and its downward trend are more pronounced than their equivalents for Latin America as a whole. Moreover, the regionwide fall is concentrated in the 1980s and 1990s, with recovery only occurring in the twenty-first century, especially as a result of the 
expansionary wage policies implemented in Argentina and Brazil. The path followed by the region is similar to that of the United Kingdom, where the fall in the wage share starts in the 1980s. The same is true in the United States, but here the sharpest decline has occurred since the 1990s. This is because the decrease in wages and salaries in the 1980s was partly offset by an increase in other employer contributions to workers, through health, insurance and pension funds.

The shares of wages and profits in GDP no longer depend solely on the wage policy, the degree of monopoly or profit margin, or the weight of the extractive sectors in the economy; but in the case of an economy like Peru's, which exports mining products and other raw materials, they will also depend on the external terms of trade. Higher international prices for these goods increase the share of profits in GDP and hence reduce the wage share. In contrast, a hike in the real minimum wage increases the share of wages in GDP. Both a rise in oil prices and a hike in interest rates on loans reduce the wage share. ${ }^{9}$ It is interesting to note that, for most of the period analysed, low inflation did not erode the share of wages in output; but at times of high inflation or hyperinflation, the result is significantly negative. Naturally, the conventional adjustment and stabilization policies also reduce the wage share.

In general, the share of wages in GDP and the economic growth rate have not trended positively, either for Peru or for Latin America as a whole. Between 1950 and 2013 the wage share declined without a significant improvement in the average rate of economic growth. In this regard, the situation is worse for Latin America than for Peru, although variability in the latter is greater than the regional average. On the other hand, an analysis by decades shows that the two variables clearly move in a direct and positive relationship, which might imply a wage-led growth regime for almost the entire period under analysis. Only in the 1990s would a profit-led regime prevail. ${ }^{10}$

Based on the Naastepad and Storm (2007) model, a system of five linear simultaneous equations was designed to determine Peru's economic growth regime. Comprehensive estimates were made for the 1942-2013 period (72 observations) using both the 3SLS method and GMM. In all cases, increases in the adjusted share of wages in GDP are positively associated with demand and the level of economic activity. In practice, however, an increase in the wage share has a negative effect on exports, which partially neutralizes the positive effect on private consumption. Nonetheless, in both estimates, private investment increases with the wage share. The joint result of considering all the effects on the demand side is that GDP increases as the wage share rises. The elasticity of GDP with respect to the wage share fluctuates between 0.36 and 0.38 . A $1 \%$ increase in the wage share increases GDP between $0.36 \%$ and $0.38 \%$, which suggests a predominantly wage-led growth regime.

A wage-led growth regime would require redistributional policies in favour of this component of national income. Yet there are also limits to such policies given their potential adverse effects on prices and the balance of payments, and because, in extreme cases, they could discourage private investment. Identifying these thresholds or limits is a complex matter, depending not only on economic factors, but also on sociopolitical and institutional ones. Nonetheless, despite these methodological caveats, this study has assumed that econometrics can reasonably be used to identify the economic growth regime. In reality, a change from one regime to another is a continuous and convoluted process that unfolds through time. The crisis in the State-directed industrialization model, adjustment and stabilization policies, and then the neoliberal structural reforms put the wage-led growth model in check. Now, with the external-sector crisis affecting many economies, particularly those that export raw materials, compounded by the new adverse scenarios that could emerge from Brexit and the election of President Trump in the United States, there is an opportunity to design and implement policies associated with a wage-led growth regime. The details and the specific magnitude of distributional policies in favour of wages and income from self-employment, which contribute to economic growth while minimizing the negative effects in other macroeconomic domains, are beyond scope of this article.

\footnotetext{
9 This effect is considered in the short-term macroeconomic model developed by Dutt and Ros (2007).

10 This was also the case in Latin America during the 1970s.
} 


\section{Bibliography}

Abeles, M., V. Amarante and D. Vega (2014), "The earnings share of total income in Latin America, 1990-2010”, CEPAL Review, No. 114 (LC/G.2629-P), Santiago, Economic Commission for Latin America and the Caribbean (ECLAC).

Alarco, G. (2016), "Distribución factorial del ingreso y regímenes de crecimiento en América Latina, 1950-2013", International Labour Review, vol. 135, No. 1, Geneva, International Labour Organization (ILO).

(2014), "Wage share and economic growth in Latin America, 1950-2011", CEPAL Review, No. 113 (LC/G.2614-P), Santiago, Economic Commission for Latin America and the Caribbean (ECLAC).

Bértola, L. and others (2008), "Income distribution in the Latin American Southern Cone during the first globalization boom, ca: 1870-1920", Working Papers in Economic History, No. 08-05, Madrid, Universidad Carlos III de Madrid.

Bhaduri, A. (2007), "On the dynamics of profit-led and wage-led growth", Cambridge Journal of Economics, vol. 32, No. 1, Oxford University Press.

Bhaduri, A. and S. Marglin (1990), "Unemployment and the real wage: the economic basis for contesting political ideologies", Cambridge Journal of Economics, vol. 14, No. 4, Oxford, Oxford University Press.

Bowles, S. and R. Boyer (1988), "Labor discipline and aggregate demand: a macroeconomic model", The American Economic Review, vol. 78, No. 2, Nashville, Tennessee, American Economic Association.

Boyer, R. (1988a), "Formalizing growth regimes within a regulation approach. A method for assessing the economic consequences of technological change", Technical Change and Economic Theory, G. Dosi and others (eds.), London, Pinter Publishers.

(1988b), "Technical change and the theory of 'regulation'”, Technical Change and Economic Theory, G. Dosi and others (eds.), London, Pinter Publishers.

Castillo, C. (2015), "Distribución factorial del ingreso en el Perú 1942-2013", thesis, Lima, University of the Pacific [online] http://repositorio.up.edu.pe/bitstream/handle/11354/1139/C\%C3\%A9sar_Tesis_maestria_2015. pdf? sequence $=1$ \&isAllowed $=\mathrm{y}$.

Cingano, F. (2014), "Trends in income inequality and its impact on economic growth", OECD Social, Employment and Migration Working Papers, No. 163, Paris, Organization for Economic Cooperation and Development (OECD).

Dutt, A. K. and J. Ros (2007), "Aggregate demand shocks and economic growth", Structural Change and Economic Dynamics, vol. 18, No. 1, Amsterdam, Elsevier.

ECLAC (Economic Commission for Latin America and the Caribbean) (2013), "Statistics and Indicators" [online] http://estadisticas.cepal.org/cepalstat/WEB_CEPALSTAT/estadisticasIndicadores.asp?idioma=e.

ECLAC/LO (Economic Commission for Latin America and the Caribbean/International Labour Organization) (2012), "Labour productivity and distribution issues", The Employment Situation in Latin America and the Caribbean, No. 6, Santiago.

Figueroa, A. (2010), "Crecimiento versus calidad de vida", Rutas hacia un Perú mejor. Qué hacer y cómo lograrlo, G. Alarco (ed.), Lima, Graduate Business School (CENTRUM) of the Catholic University of Peru/Aguilar.

Fitzgerald, V. (2009), "La distribución de ingresos y rentas en América Latina durante el siglo XX: un estudio inicial", Cuadernos Económicos de ICE, No. 78, Madrid.

Frankema, E. (2009), "Reconstructing labour income shares in Argentina, Brazil and Mexico, 1870-2000", Working Paper, Utrecht, Utrecht University.

García, N. (2013), "Fast economic growth and income distribution (Peru 1990-2010)", Economie Appliquée, No. 1 [online] http://www.itf.org.ar/pdf/documentos/89_2013.pdf.

ILO (International Labour Organization) (2012), 2012 Labour Overview. Latin America and the Caribbean, Lima, ILO Regional Office for Latin America and the Caribbean.

(2011), "Towards a sustainable recovery: the case for wage-led policies", International Journal of Labour Research, vol. 3, No. 2, Geneva.

Kaldor, N. (1955), "Alternative theories of distribution", The Review of Economic Studies, vol. 23, No. 2, Oxford University Press.

Kalecki, M. (1954), Theory of Economic Dynamics. An Essay on Cyclical and Long-Run Changes in Capitalist Economy, London, Allen \& Unwin Ltd.

Keynes, J. M. (1936), The General Theory of Employment, Interest and Money, New York, Harcourt, Brace and Company. 
Kumhof, M. and R. Rancière (2010), "Inequality, leverage and crises", IMF Working Paper, No. WP/10/268, Washington, D.C., International Monetary Fund (IMF).

Lakner, C. and B. Milanovic (2015), "La distribución global del ingreso de la caída del Muro de Berlín a la Gran Recesión", Revista de Economía Institucional, vol. 17, No. 32, Bogota, Universidad Externado de Colombia.

Lindenboim, J. (2008), "Distribución funcional del ingreso, un tema olvidado que reclama atención", Problemas del Desarrollo, vol. 39, No. 153, Mexico City, National Autonomous University of Mexico.

Maddison, A. (2001), The World Economy. A Millennial Perspective, Paris, Organization for Economic Cooperation and Development (OECD).

Marshall, A. (1890), Principles of Economics, London, Macmillan and Company.

Ministry of Finance and Trade (1959), Anuario Estadístico del Perú 1956-1957, Lima, Department of Statistics and Censuses.

Naastepad, C. W. M. and S. Storm (2007), "OECD demand regimes (1960-2000)", Journal of Post Keynesian Economics, vol. 29, No. 2, Taylor \& Francis.

Neira Barría, V. (2010), "Distribución factorial del ingreso en América Latina, 1950-2000: nuevas series a partir de las cuentas nacionales", Working Paper, Barcelona, Pompeu Fabra University.

Nikiforos, M. (2014), "Distribution-led growth in the long run", Working Paper, No. 814, New York, Levy Economics Institute of Bard College.

Onaran, Ö. and G. Galanis (2012), "Is aggregate demand wage-led or profit-led? National and global effects", Conditions of Work and Employment Series, No. 40, Geneva, International Labour Organization (ILO).

Onaran, Ö., E. Stockhammer and L. Grafl (2011), "Financialisation, income distribution and aggregate demand in the USA", Cambridge Journal of Economics, vol. 35, No. 4, Oxford University Press. (2009), "The finance-dominated growth regime, distribution, and aggregate demand in the US", Department of Economics Working Paper, No. 126, Vienna, Vienna University of Economics and Business.

Ostry, J., A. Berg and G. Tsangarides (2014), "Redistribution, inequality, and growth", IMF Staff Discussion Note, No. SDN/14/02, Washington, D.C., International Monetary Fund (IMF).

Oxfam (2014), Iguales: acabemos con la desigualdad extrema. Es hora de cambiar las reglas [online] http://www.oxfamintermon.org/sites/default/files/documentos/files/InformelGUALES_Acabemos AcabemosConlaDesigualda.pdf.

Palley, T. (2014), "Rethinking wage vs. profit-led growth theory with implications for policy analysis", IMK Working Paper, No. 141, Düsseldorf, Macroeconomic Policy Institute.

Pedagua, L. E. (2009), "Alternativas metodológicas para el empalme estadístico de series temporales: caso Venezuela 1950-2005", Temas de Coyuntura, No. 59, July.

Piketty, T. (2014), El capital en el siglo XXI, Mexico City, Fondo de Cultura Económica.

Piketty, T. and G. Zucman (2013), "Capital is back: wealth-income rations in rich countries, 1700-2010", Working Paper, Paris, Paris School of Economics.

Quesnay, F. (1980). “La 'tercera edición' del 'Tableau Économique'”, El Tableau Économique de Quesnay, M. Kuczynski and R. L. Meek (eds.), Mexico City, Fondo de Cultura Económica.

Ricardo, D. (1821), On the Principles of Political Economy and Taxation, London, John Murray.

Seminario, B. (2015), El desarrollo de la economía peruana en la era moderna. Precios, población, demanda y producción desde 1700, Lima, University of the Pacific.

Smith, A. (2010), An Inquiry into the Nature and Causes of the Wealth of Nations, London, Strahan.

Stiglitz, J. (2015), La gran brecha. Qué hacer con las sociedades desiguales, Barcelona, Taurus.

Stockhammer, E. (2011), "Wage-led growth: an introduction", International Journal of Labour Research, vol. 3, No. 2, Geneva, International Labour Organization (ILO).

Stockhammer, E. and S. Ederer (2007), "Demand effects of the falling wage share in Austria", Department of Economics Working Paper, No. 106, Vienna, Vienna University of Economics and Business.

Stockhammer, E., E. Hein and L. Grafl (2011), "Globalization and the effects of changes in functional income distribution on aggregate demand in Germany", International Review of Applied Economics, vol. 25, No. 1, Taylor \& Francis.

Stockhammer, E. and Ö. Onaran (2004), "Accumulation, distribution and employment: a structural VAR approach to a Kaleckian macro model", Structural Change and Economic Dynamics, vol. 15, No. 4, Amsterdam, Elsevier.

Stockhammer, E., Ö. Onaran and S. Ederer (2009), "Functional income distribution and aggregate demand in the Euro area", Cambridge Journal of Economics, vol. 33, No. 1, Oxford University Press.

World Bank (2014), "World Development Indicators" [online] http://databank.worldbank.org/ddp/home. do?Step=1\&id=4). 